
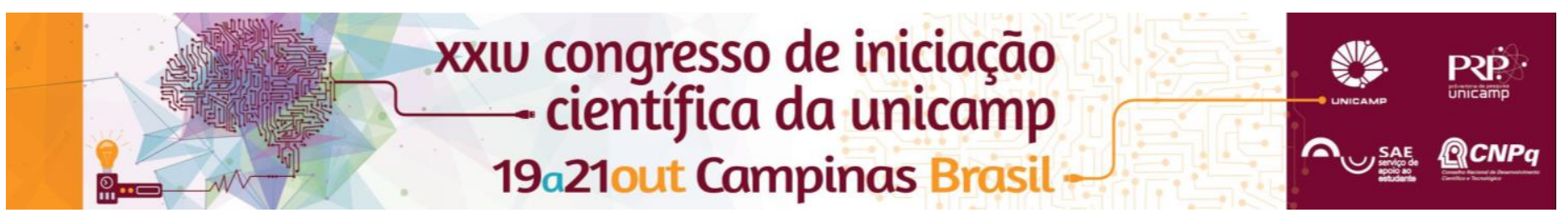

\title{
Moral sexual e subjetividade em Júlia Lopes de Almeida.
}

\section{Gabriela Simonetti Trevisan*.}

\section{Resumo}

Utilizando-me de duas obras publicadas pela escritora carioca Júlia Lopes de Almeida (1862-1934) - A falência (1901) e Eles e elas (1910) -, busco analisar como as personagens femininas dessa autora reproduzem, criticam e fogem dos discursos masculinos e normativos apoiados na medicina, no século XIX e início do XX. Para tanto, me inspiro nos conceitos de "dispositivo da sexualidade" e "heterotopia", de Michel Foucault.

\section{Palavras-chave:}

Júlia Lopes de Almeida, heterotopias, subjetividade.

\section{Introdução}

O romance A falência ${ }^{1}$ se passa em 1891 e conta a história da família Teodoro, que possui um armazém de café e se constituiu a partir de um casamento arranjado, permeado de adultérios. Após a falência devido ao Encilhamento, Francisco Teodoro, o patriarca, se suicida, fazendo com que as mulheres da casa precisem encontrar formas de se sustentarem e cuidarem umas das outras. Já Eles e elas ${ }^{2}$ se constitui de um compilado de crônicas que intercalam narradores masculinos e femininos, tratando dos temas do mundo privado, sendo as mulheres muito críticas ao cerceamento de suas liberdades e os homens quase sempre tratados de forma escrachada e humorística. Nesse sentido, analiso como suas personagens e narradoras femininas buscam linhas de fuga dos discursos patriarcais que naturalizam o lugar social da mulher enquanto mãe e dona-de-casa, sem deixarem, porém, de reproduzirem essas mesmas ideias em alguns momentos.

\section{Resultados e Discussão}

Os discursos masculinos científicos e biologizantes que criam uma ideia de mulher inerente à maternidade se fortalecem no Brasil no século XIX, inspirados pelas teorias que emergem na Europa desde o século XVIII. Dessa forma, aquelas que negassem essa naturalidade de seu corpo eram vistas como anormais. É nesse sentido que Foucault chama atenção para o que denomina "dispositivo da sexualidade"3, ou seja, a partir dessa ascensão da ciência, há uma rede de saberes e poderes que produzem um conjunto de discursos e práticas sobre o sexo e que o capturam e o normatizam, instituindo o que seria considerado normal e o que não seria. Com esse dispositivo, é produzida uma série de tratados acerca dos comportamentos sexuais femininos.

Escrevendo nesse mesmo momento histórico, Júlia Lopes de Almeida cria personagens que também reproduzem essas ideias, mas que, principalmente, criticam a normatização sobre seus corpos e comportamentos, mostrando-se mais múltiplas do que o ideal masculino da época. Busco analisar, portanto, as linhas de fuga construídas por essas mulheres dentro das histórias da escritora. Mila, de A falência, por exemplo, é uma mãe e esposa com desejos sexuais além da reprodução, o que iria contra a moral dos discursos médicos. Para realizar-se, busca no amante a satisfação sexual não obtida no casamento. Já uma das narradoras de Eles e elas reclama da dependência financeira do marido e de como se sente humilhada por essa situação de inferiorização.
Dessa forma, utilizo o conceito de "heterotopia", também de Foucault, para tratar dos outros espaços subjetivos criados por essas personagens ao tentarem escapar da normatização. Segundo o filósofo, as heterotopias são espaços outros, "espécies de contraposicionamentos, espécies de utopias efetivamente realizadas" ", ou seja, são espaços reais reinventados. Essas personagens construiriam heterotopias subjetivas, espaços de liberdade nos quais poderiam ser múltiplas e não corresponderem ao modelo mãe-esposa e dona-de-casa.

\section{Conclusões}

As personagens de Júlia Lopes de Almeida, nas obras A falência e Eles e elas, criam espaços subjetivos heterotópicos para si mesmas a partir do pensamento crítico, das ações subversivas e das amizades entre si. Elas não se veem como parte de um modelo uno de mulher e se colocam como dotadas de ambição, desejos sexuais, capacidade de administração, de serem amigas e de ajuda mútua, ficando revoltadas com os esforços para subjugá-las. Mila e as mulheres da família se unem em uma casa, trabalhando e se educando para sobreviverem. Já as narradoras femininas de Eles e elas não aceitam a submissão aos maridos e criticam as desigualdades de gênero na sociedade. Dessa forma, ainda que elas também reproduzam ações e falas machistas, Júlia apresenta um mundo feminino mais plural e insubmisso do que dizia a moral masculina.

\section{Agradecimentos}

Agradeço à minha orientadora Dra. Luzia Margareth Rago e a todo o grupo de orientação pelo engrandecimento da pesquisa. Obrigada também à minha família pelo apoio. Por fim, agradeço ao $\mathrm{PIBIC/CNPq}$ pela concessão da bolsa de financiamento que possibilitou esta pesquisa e ao XXIV Congresso de Iniciação Científica da Unicamp pela possibilidade de divulgação da mesma.

${ }^{1}$ ALMEIDA, Júlia Lopes de. A falência. São Paulo: Hucitec, 1978 (1 ${ }^{\mathrm{a}}$ publicação em 1901).

edição.

Eles e elas. Rio de Janeiro: Francisco Alves \& Cia, 1910, 2

${ }^{3}$ FOUCAULT, Michel. História da Sexualidade I: a vontade de saber. Rio de Janeiro: Graal, 1993, $11^{\text {a }}$ edição. Tradução de Maria Thereza da Costa Albuquerque

"Outros espaços". In: Ditos e escritos III. Rio de Janeiro: Forense Universitária, 2009, $2^{\mathrm{a}}$ edição. Tradução de Inês Autran Dourado Barbosa. Pp. 415. 